\title{
ANALISIS POTENSI PEMANFAATAN RUANG TERBUKA HIJAU (RTH) KAMPUS DI POLITEKNIK NEGERI BANDUNG
}

\author{
Wida Oktavia Suciyani \\ Prodi Manajemen Aset, Jurusan Administrasi Niaga Politeknik Negeri Bandung \\ Penulis Korespondensi e-mail : wida.oktavia@polban.ac.id
}

\begin{abstract}
The Research on " Analysis Potential Utilization of Green Open Space (RTH) Campus at Bandung State Polytechnic" is motivated by a problem about RTH that has not been utilized optimally in accordance with its function. The purpose of this research is to analyze the potential utilization of RTH campus Polban that can still be developed, so it can create a sustainable campus environment. This research method uses qualitative approach by using applied research, beside that the data collection techniques by using Triangulation (observation, interview, and documentation study) and analysis technique in this research is descriptive. Based on the analysis result, it is known that the existing condition of RTH of Polban campus has not been utilized optimally according to RTH function due to the lack of facilities which can support activities of socio-cultural, economic, and aesthetic functions.
\end{abstract}

Keywords: Potential Utilization, Green Open Space Campus.

\begin{abstract}
ABSTRAK
Penelitian mengenai “Analisisi Potensi Pemanfaatan Ruang Terbuka Hijau (RTH) Kampus di Politeknik Negeri Bandung” dilatarbelakangi oleh suatu permasalahan mengenai RTH yang belum dimanfaatkan secara optimal sesuai dengan fungsinya. Tujuan penelitian ini adalah untuk menganalisis potensi pemanfaatan RTH kampus Polban yang masih dapat dikembangkan sehingga dapat menciptakan lingkungan kampus yang berkelanjutan. Metode pada penelitian ini menggunakan pendekatan kualitatif dengan jenis penelitian terapan (applied research), selain itu teknik pengumpulan data dengan menggunakan Triangulasi (observasi, wawancara, dan studi dokumentasi) dan teknik analisis dalam penelitian ini bersifat deskriptif. Berdasarkan hasil analisa diketahui kondisi eksisting RTH kampus Polban belum dimanfaatkan secara optimal sesuai fungsi RTH dikarenakan minimnya fasilitas yang dapat menunjang kegiatan berupa fungsi sosial budaya, ekonomi, dan estetika.
\end{abstract}

Kata kunci: Potensi Pemanfaatan, Ruang Terbuka Hijau kampus. 
Jurnal Planologi Vol. 15, No. 1, April 2018

Available : http://jurnal.unissula.ac.id/index.php/psa

\section{PENDAHULUAN}

Gerakan Go Green menjadi salah satu program Kementrian Lingkungan Hidup dan banyak komunitas. Didalam program tersebut, terdapat suatu konsep yang dapat diamanatkan kepada berbagai aktivitas kegiatan, salah satunya pada lingkungan kampus dengan konsep eco-campus atau Green Campus, sehingga dapat ikut berperan sertan dalam menyelesaikan pelestarian lingkungan. The International Alliance of Research Universities (2007) menyebutkan lingkungan kampus dapat memberikan dukungan yang terhadap pengurangan pemanasan global dan kerusakan lingkungan, salah satunya dengan cara menerapkan konsep Green Campus, suatu konsep yang mengedepankan penyedian dan pemanfaatan Ruang Terbukan Hijau (RTH) di lingkungan kampus. Selain untuk mengatasi berbagai permasalahan lingkungan, RTH juga dapat dimanfaatkan sebagai tempat mahasiswa untuk melakukan aktivitas sosial dan sebagai ruang belajar luar (open learning space).

Menurut Peraturan Menteri Pekerjaan Umum Nomor 5 Tahun 2008 tentang Pedoman Penyedian dan Pemanfaatan Ruang Terbuka Hijau di Kawasan Perkotaan, pengertian Ruang Terbuka Hijau (RTH) adalah area memanjang atau jalur, dan atau mengelompok yang penggunaannya lebih bersifat terbuka, tempat tumbuh tanaman baik yang tumbuh secara alamiah maupun buatan. Sedangkan menurut Hakim (2004), RTH adalah bagian dari ruang terbuka yang diisi oleh tanaman, tumbuhan dan vegetasi guna mendapatkan manfaat keamanan, kenyamanan, kesejahteraan dan keindahan suatu kawasan.

Merujuk pada kriteria ideal penyediaan RTH yang diatur dalam Undang-undang Penataan Ruang Nomor 26 tahun 2007, disebutkan bahwa proporsi luasan RTH suatu perkotaan yakni sebesar $30 \%$ dari luas wilayahnya. Proporsi tersebut terdiri dari $20 \%$ RTH publik dan 10\% RTH Privat. Sedangkan pemanfaatan RTH dapat ditinjau berdasarkan fungsinya yakni fungsi instrinsik (fungsi ekologis) dan fungsi ekstrinsik yang meliputi fungsi sosial budaya, ekonomi, dan estetika.

Penataan ruang dan lingkungan merupakan salah satu upaya dalam mengintervensi keseimbangan pertumbuhan wilayah. Definisi penataan ruang sebagaimana tertuang dalam Undang-undang nomor 26 tahun 2007 tentang Penaatan Ruang adalah suatu sistem dari proses berkesinambungan yang terdiri dari perencanaan tata ruang, pemanfaatan ruang, dan pengendalian pemanfaatan ruang. 
Jurnal Planologi Vol. 15, No. 1, April 2018

Dalam ruang terjadi suatu proses pencarian solusi dari segala banyak kepentingan dari berbagai pihak atau stakeholder (Irfan, 2009). Kesepakatankesepakatan tersebut sebagai upaya dari pengelolaan sumber daya alam berupa ruang yang tertata, optimal, efisien dan berdaya guna. Dari konsep tersebut maka dapat diambil pengertian bahwa penataan ruang merupakan konsep pemikiran atau gagasan disemua aspek kegiatan dalam suatu wilayah kawasan (Tarigan, 2010).

Ruang Terbuka Hijau (RTH) merupakan bagian dari ruang-ruang terbuka (open spaces) dalam penataan ruang suatu perkotaan yang diisi oleh tumbuhan, tanaman, dan vegetasi (endemik, introduksi) guna mendukung manfaat langsung dan/atau tidak langsung yang dihasilkan oleh RTH dalam kota tersebut yaitu keamanan, kenyamanan, kesejahteraan, dan keindahan wilayah perkotaan (Permen PU No. 5/PRT/2008). Ruang terbuka hijau di klasifikasi berdasarkan status kawasan, bukan berdasarkan bentuk dan struktur vegetasinya (Riswandi, 2004). Pada ruang terbuka hijau, penggunaanya kea rah bersifat pengisian kompoen hijau tanaman atau vegetasi yang alamiah ataupun penggunaan lahan budidaya bersifat tanaman seperti pada lahan sawah, kebun dan sebagaianya.

Menurut Arifin dan Nurhayati (2000), RTH merupakan sebidang lahan yang ditata sedemikian rupa sehingga mempunyai keindahan, kenyamanan dan keamanan bagi pemiliknya atau penggunanya yang bernilai estetika dan berfungsi sebagai ruang terbuka dengan fungsinya yang beragam. Pada Penelitian ini, Peneliti akan mengkaji terkait penyediaan dan pemanfaatan RTH di Kampus Polban. Hal tersebut dilakukan agar Polban dapat menjaga ketersediaan lahan hijau sebagai daerah resapan, menjaga aspek planologis kampus, menjaga keserasian lingkungan kampus, serta menciptakan kampus yang nyaman, bersih, dan sehat untuk penghuninya.

Merujuk pada Permen PU No.5/2008 tentang penyediaan dan pemanfaatan RTH perkotaan, pemanfaatan RTH dapat mengacu pada fungsi tambahan (ekstrintik) yakni sebagai fungsi sosial dan budaya, ekonomi, serta estetika. Berdasarkan lokasi penelitian yang berada di wilayah Kampus, maka pemanfaatan RTH disesuaikan yakni sebagai sarana penunjang pendidikan.

Berdasarkan fungsinya, RTH dapat dijadikan sebagai ruang terbuka publik yang sangat berperan dalam memperbaiki kualitas hidup masyarakat yang sejalan dengan kebutuhan manusia dalam melakukan kegiatan bersama (Siahaan, 2010). Ruang terbuka publik yang baik, ditandai dengan ketertarikan masyarakat untuk memanfaatkannya dan juga ditunjukkan dengan kemudahan mengunjunginya (Carmona, et al. 2003). Selain itu 
Jurnal Planologi Vol. 15, No. 1, April 2018

Available : http://jurnal.unissula.ac.id/index.php/psa

karakter ruang terbuka publik ditandai dengan: 1) Ruang tempat masyarakat berinteraksi, melakukan beragam kegiatan secara berbagi dan bersama, meliputi interaksi sosial, ekonomi dan budaya, dengan penekanan utama pada aktivitas sosial; 2) Ruang yang diadakan, dikelola, dan dikontrol secara bersama, baik oleh instansi publik maupun privat; 3) Ruang yang terbuka dan aksesibel secara visual maupun fisik bagi semua tanpa kecuali; dan 4) Ruang dimana masyarakat mendapat kebebasan beraktivitas (Sunaryo, 2010). Nuansa interaksi sosial dalam kampus secara tidak langsung menjadi laboratorium nyata dalam membangun kepribadian untuk mempersiapkan diri di dunia kerja.

Merujuk pada Peraturan Menteri No.1 Tahun 2007 tentang Penataan Ruang Terbuka Hijau Kawasan Perkotaan, salah satu manfaat dari RTH adalah sebagai sarana pendidikan. Oleh karenanya, penyediaan dan pemanfaatan RTH pada kawasan kampus dapat dijadikan sebagai ruang publik dan ruang belajar luar (open learning space). Sekarang ini, konsep pembelajaran mandiri menjadi konsep pembelajaran yang banyak digunakan perguruan tinggi. Menurut Mudjiman (2007), belajar mandiri merupakan kegiatan belajar yang bersifat aktif guna mendorong keinginan atau motivasi untuk menguasai suatu kompetensi tertentu. Guna menggali kompetensi tersebut, mahasiswa secara aktif melakukan proses pembelajaran dengan mencari informasi dari berbagai sumber lalu mengolahnya, sehingga pembelajaran terfokus pada pemecahan suatu masalah (Problem Based Learning). Guna mendukung metode pembelajaran mandiri, salah satu yang perlu diperhatikan oleh perguruan tinggi yakni ketersediaan tempat belajar (Mudjiman, 2007). Terdapat beberapa ruang atau tempat untuk belajar, namun dalam konsep belajar mandiri kali ini akan dibahas mengenai ruang belajar terbuka atau open learning space.

Menurut Educause (2011), Open Learning space atau ruang belajar (di luar kelas) dalam konsep modern merupakan sebuah tempat pertemuan yang menawarkan suatu area untuk memfasilitasi dan mengakomodasi peserta didik dalam melaksanakan kegiatan sesi diskusi di tempat yang tenang dan nyaman. Sedangkan menurut Brown dan Lippicott (2013), ruang belajar merupakan suatu area pertemuan peserta didik untuk saling berdiskusi, mengemukakan pendapat tentang tugas atau perkuliahannya, dengan segala fasilitas untuk kenyamanan dan keamanan belajar dilengkapi jaringan atau koneksi internet seperti wifi dan sumber belajar lain untuk memperluas interaksi mahasiswa. Ruang belajar terbuka atau open learning space dapat menjadi tempat yang 
Jurnal Planologi Vol. 15, No. 1, April 2018

Available: http://jurnal.unissula.ac.id/index.php/psa

ideal untuk berbaur, tatap muka dengan pertemuan virtual, yang memungkinkan seluruh peserta didik untuk bergabung dalam diskusi proyek (Educause, 2011).

Guna mendukung keberhasilan pelaksanaan belajar mandiri secara efektif, penyediaan Open learning space perlu juga dilengkapi dengan sumber informasi, narasumber atau pembantu belajar, dukungan, dan suasana lingkungan yang kondusif. Menurut Mudjiman (2007), ketersediaan sumber informasi diperlukan karena proses pembelajaran mandiri sangat memungkinkan mendorong peserta didik mencari informasi terbaru pada surat kabar, buku, jurnal, atau internet. Ketersediaan pembantu belajar seperti pendidik atau teman juga penting sebagai teman diskusi, sharing atau tempat bertukar pikiran. Selain itu, yang perlu diperhatikan pada Open learning space adalah ketersediaan suasana lingkungan yang kondusif, tenang, sehat baik secara fisik (ruangan yang cukup keluasannya, kelengkapan, dan penerangan) maupun secara mental (keakraban, kerja sama, atau sikap akademiknya) yang akan sangat menunjang kegiatan belajar. Menurut McDaniel (2014), kelengkapan lain yang dapat mempengaruhi kelancaran belajar di ruang belajar terbuka atau open learning space adalah ketersediaan fasilitas seperti: meja, kursi kerja atau belajar.

Sebagai salah satu Perguruan Tinggi di Kota Bandung, Polban memiliki luas lahan sebesar $205.125 \mathrm{~m}^{2}$ dan luas lahan yang diperuntukkan sebagai RTH yakni sebesar $115.742 \mathrm{~m}^{2}$. Berdasarkan hal tersebut, Polban memiliki luas RTH sebesar 56,42\% dari luas lahan keseluruhan. Meskipun Polban telah memenuhi kriteria penyediaan RTH yang melebihi $30 \%$, akan tetapi fungsi penyediaan dan pemanfaatan RTH di Kampus Polban saat ini masih bersifat pasif. Hal tersebut dikarenakan hampir sebagaian besar RTH di kawasan Kampus Polban saat ini hanya berfungsi ekologis (seperti: penghijauan dan resapan air) dan kurangnya upaya pemanfaatan RTH untuk fungsi lainnya seperti sosial budaya, estetika, dan ekonomi.

Berdasarkan permasalahan mengenai RTH yang belum dimanfaatkan secara optimal sesuai dengan fungsinya maka tujuan penelitian ini adalah untuk menganalisis potensi pemanfaatan RTH kampus Politeknik Negeri Bandung yang masih dapat dikembangkan sehingga dapat menciptakan lingkungan kampus yang berkelanjutan.

\section{METODOLOGI}

Metode penelitian merupakan rancangan dan strategi pengumpulan, analisis, dan interpretasi data (Creswell, 2009). Pada penelitian ini, metode yang digunakan yakni menggunakan pendekatan kualitatif dengan jenis penelitian terapan (applied research).

Wida Oktavia Suciyani I 21 Analisis Potensi Pemanfaatan Ruang Terbuka Hijau ... 
Jurnal Planologi Vol. 15, No. 1, April 2018

Available : http://jurnal.unissula.ac.id/index.php/psa

Menurut Gay (dalam Sugiyono, 2009) penelitian terapan adalah penelitian yang dilakukan dengan tujuan menerapkan, menguji dan mengevaluasi kemampuan suatu teori yang diterapkan dalam memecahkan masalah-masalah praktis. Selain itu, jenis metode penelitian yang diaplikasikan dalam penelitian ini adalah jenis "metode deskriptif" yakni cara menggambarkan kondisi lapangan untuk mengungkap secara akurat mengenai berbagai keadaan di lapangan pada saat penelitian berlangsung (Sugiama, 2008).

Sumber data yang digunakan yakni data primer dan data sekunder. Menurut Arikunto (2006) sumber data dalam penelitian adalah subyek dari mana data dapat diperoleh. Sedangkan teknik pengumpulan data yang digunakan dalam penelitian ini adalah teknik Triangulasi (observasi, wawancara, dan studi dokumentasi). Menurut Nasution (2003) Teknik Triangulasi dapat digunakan untuk mengecek kebenaran data dan juga untuk memperkaya data dilapangan. Data Primer diperoleh dengan cara melakukan observasi lapangan pada RTH di area Kampus Polban dan wawancara pada pengelola aset POLBAN sebagai pihak yang mengetahui informasi mengenai penyediaan dan pemanfaatan RTH kampus. Sedangkan data sekunder yang digunakan yakni bersumber dari dokumen mengenai Izin Lingkungan Kegiatan Kampus Polban. Teknik Analisis dalam penelitian ini bersifat deskriptif yakni mendeskripsikan kembali secara tertulis hasil observasi dilapangan dengan teori yang didapatkan dari hasil literatur.

\section{HASIL DAN PEMBAHASAN}

Berdasarkan Rencana Tata Ruang Wilayah (RTRW) Kota Bandung, secara administratif Polban berada pada wilayah Kabupaten Bandung Barat dan termasuk pada Kawasan Bandung Utara (KBU) yang merupakan daerah resapan air, sehingga dalam implementasi perencanaan kawasan perlu merujuk pada aturan yang berlaku. Selain itu, berdasarkan Peraturan Gubernur Jawa Barat Nomor 21 Tahun 2009 tentang Petunjuk Pelaksanaan Peraturan Daerah Provinsi Jawa Barat Nomor 1 Tahun 2008 Tentang Pengendalian Pemanfaatan Ruang Kawasan Bandung Utara, ditetapkan bahwa luasan Koefisien Dasar Hijau (KDH) minimal sebesar 52\% dari luasan keseluruhan daerah perencanaan.

Merujuk pada Keputusan Bupati Bandung Barat Nomor 530/Kep.166-KLH/ 2016 tentang Izin Lingkungan Kegiatan Kampus Polban, luas lahan keseluruhan yakni sebesar $205.125 \mathrm{~m}^{2}$ dan luas lahan yang peruntukkan sebagai Ruang Terbuka Hijau 
Jurnal Planologi Vol. 15, No. 1, April 2018

Available : http://jurnal.unissula.ac.id/index.php/psa

(RTH) yakni sebesar $115.742 \mathrm{~m}^{2}$. Berdasarkan hal tersebut, Polban memiliki luas RTH sebesar 56,42\% dari luas lahan keseluruhan . Oleh karena itu, secara fisik luas lahan RTH Kampus Polban telah memenuhi kriteria jumlah minimum luasan RTH yang melebihi 52\% sebagaimana ditetapkan dalam aturan.

Merujuk pada Peraturan Menteri Pekerjaan Umum No.5 Tahun 2008, penyediaan dan pemanfaatan RTH dapat ditinjau berdasarkan luas dan lokasi lahan potensial, struktur dan pola yang mungkin dikembangkan, serta kriteria vegetasi yang sesuai dengan kepentingan pengembangannya. Guna mengetahui lokasi serta luas lahan RTH yang potensial, maka dapat ditinjau berdasarkan fungsi dasar penyediaan dan pemanfaatan RTH yakni sebagai fungsi ekologis, fungsi sosial dan budaya, fungsi ekonomi, serta fungsi arsitektural/estetika. Oleh karenanya, diharapkan penyediaan dan pemanfaatan RTH Kampus akan mampu menstimulasi kreativitas dan produktivitas warga kampus serta dapat menciptakan 'keseimbangan kehidupan fisik dan psikis'. Berdasarkan hal tersebut, maka pemenuhan fungsi dasar RTH dapat menjadi tolok ukur keberhasilan penyediaan dan pemanfaatan RTH Kampus yang berkinerja tinggi di Polban.

Berdasarkan hasil survey lapangan yang telah dilakukan disekitar Kampus Polban, terdapat 21 (dua puluh satu) lokasi RTH yang tersebar dibeberapa area kampus, baik yang terpusat maupun yang berada disekitar area gedung perkuliahan. Guna mengidentifikasi lokasi RTH yang berpotensi untuk dapat dioptimalkan fungsi penggunaan dan pemanfaatannya, maka dibuat pemetaan lokasi RTH Kampus Polban berupa Peta Panel Lokasi Strategis Pengembangan RTH. Peta tersebut dibuat menjadi 8 (delapan bagian). Pada bagian pertama, sebagaimana dapat dilihat pada Gambar 4.5 menunjukkan lokasi RTH yang berlokasi di depan menara air utara (1) dan di samping Gedung Laboratorium Aeronautika (2). 


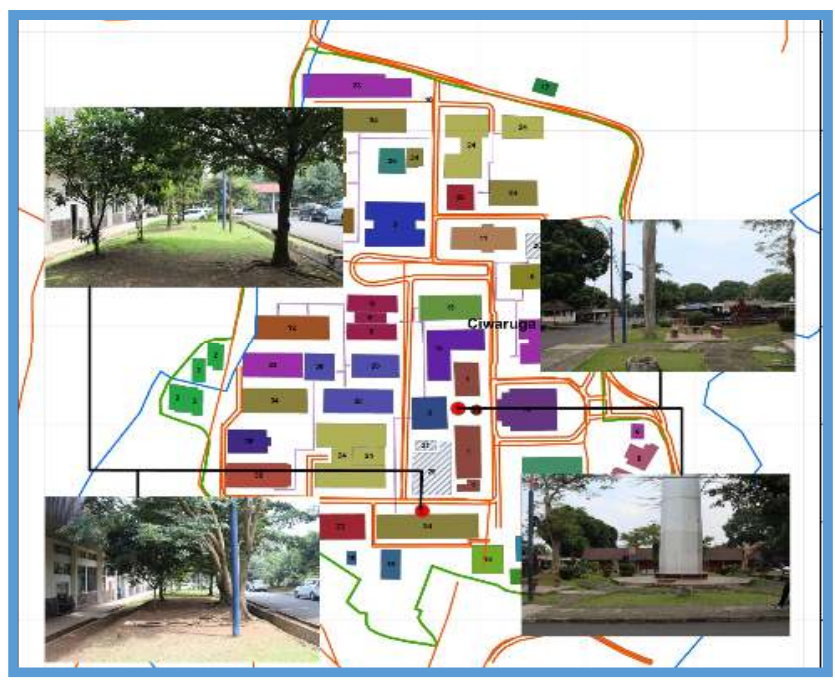

Gambar 1 Peta Potensi Lokasi Strategis ke-1 Pengembangan RTH Kampus Polban Sumber: Hasil Dokumentasi, 2017

Berdasarkan Gambar 1, ditunjukkan bahwa dikedua lokasi tersebut sangat berpotensi untuk dilakukan pengembangan RTH. Pada taman yang berlokasi di depan menara air utara saat ini sudah memenuhi fungsi sosial budaya sebagai tempat yang memfasilitasi warga kampus untuk melakukan interaksi sosial yang ditunjukkan dengan adanya fasilitas kursi, namun hanya perlu dilengkapi dengan berbagai fasilitas lainnya yang menunjang seperti meja dan lampu taman. Akan tetapi berdasarkan lokasinya yang strategis berada dijalan utama kawasan Kampus Polban, RTH tersebut dapat juga dikembangkan menjadi icon Kampus dengan sentuhan arsitektural sehingga dapat memenuhi fungsi estetika. Begitu pula, dengan taman yang berada disamping Gedung Laboratorium Aeronautika saat ini hanya berfungsi sebagai ekologis saja dimana hanya ada pepohonan rindang diatas lahannya. Berdasarkan hasil pengamatan, lahan tersebut berpotensi untuk dioptimalkan pemanfaatannya sebagai tempat mahasiswa melaksanakan aktivitas sosial budaya dengan menambahkan fasilitas seperti kursi, meja, lampu taman, dan jaringan listrik . 


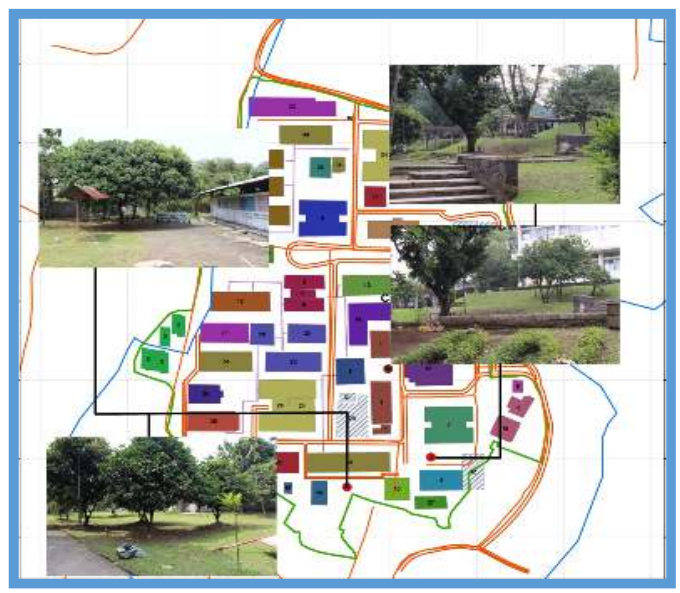

Gambar 2 Peta Potensi Lokasi Strategis ke-2 Pengembangan RTH Kampus POLBAN Sumber: Hasil Dokumentasi, 2017

Berdasarkan Gambar 2, ditunjukkan bahwa terdapat RTH yang terletak di depan Gedung Administrasi Niaga (3) dan di samping Pujasera (4). Berdasarkan hasil pengamatan dikedua lokasi tersebut, sudah terdapat beberapa fasilitas seperti kursi, alat panjat tebing yang mendukung fungsi sosial budaya, serta terdapat beragam pepohonan penghasil buah yang dapat dikonsumsi warga kampus yang mendukung fungsi ekonomi. Hal tersebut telah mencerminkan adanya fungsi sosial budaya dan ekonomi, namun perlu ada upaya pengembangan dengan menambahkan beberapa fasilitas seperti meja, proteksi cuaca, jaringan listrik, lampu taman, jaringan internet.

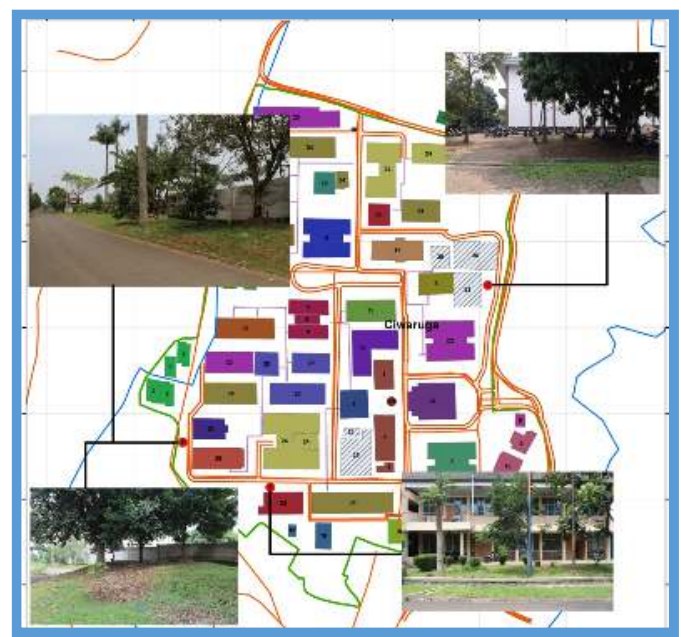

Gambar 3 Peta Potensi Lokasi Strategis ke-3 Pengembangan RTH Kampus POLBAN Sumber: Hasil Dokumentasi, 2017

Gambar 3 menunjukkan RTH yang berada di depan labolatorium Teknik Kimia (5); di depan Asrama Mahasiswa (6); dan di area parkir mahasiswa (7). Berdasarkan 
Jurnal Planologi Vol. 15, No. 1, April 2018

Available : http://jurnal.unissula.ac.id/index.php/psa

hasil survey lapangan, Taman yang terletak di depan labolatorium Teknik Kimia dan di depan Asrama Mahasiswa sudah dimanfaatkan secara optimal. Berdasarkan hasil pengamatan, dilokasi tersebut jarang dilalui oleh mahasiswa, untuk itu upaya pemanfaatan yang dapat dilakukan di atas lahan tersebut yakni dengan menanam beragam jenis pepohonan rindang. Sedangkan untuk Taman yang terletak disekitar area parkir sementara mahasiswa, berpotensi untuk dikembangkan sebagai ruang publik dan ruang belajar terbuka yang dapat menunjang aktivitas mahasiswa Jurusan Akuntansi dengan menambahkan berbagai fasilitas seperti kursi, meja, lampu taman, proteksi cuaca, jaringan listrik, dan jaringan internet.

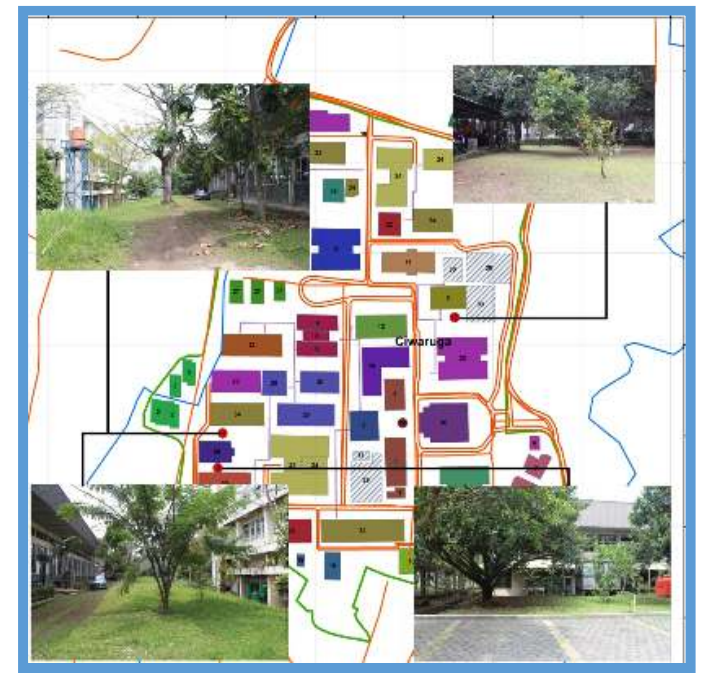

Gambar 4 Peta Potensi Lokasi Strategis ke-4 Pengembangan RTH Kampus POLBAN Sumber: Hasil Dokumentasi, 2017

Gambar 4 diatas menunjukkan RTH yang terletak diantara Gedung U dan Lab. Teknik Refrigerasi (8); diantara Gedung U dan Lab. Teknik Mesin (9); di depan Gedung Akuntansi (10). Berdasarkan hasil pengamatan, Taman yang terletak diantara Gedung U dan Lab. Teknik Refrigerasi sudah dimanfaatkan secara optimal, dimana lahan tersebut ditanami pepohonan rindang, akan tetapi sulit untuk dikembangkan lagi dikarenakan luas lahannya yang tidak terlalu besar. Sedangkan untuk Taman yang berada diantara Gedung U-Lab. Teknik mesin dan Taman disamping Gedung akuntansi berpotensi untuk dikembangkan menjadi ruang publik guna mendukung fungsi sosial budaya, sehingga perlu difasilitasi dengan berbagai sarana seperti kursi, meja, proteksi cuaca, lampu taman, dan jaringan listrik guna memudahkan mahasiswa untuk melakukan berbagai aktivitas di Polban. 
Jurnal Planologi Vol. 15, No. 1, April 2018 Available : http://jurnal.unissula.ac.id/index.php/psa

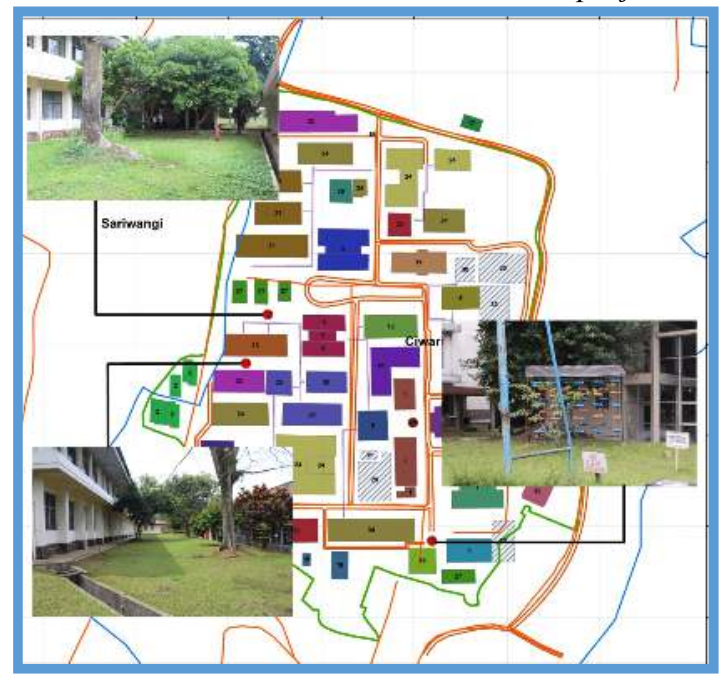

Gambar 5 Peta Potensi Lokasi Strategis ke-5 Pengembangan RTH Kampus POLBAN Sumber: Hasil Dokumentasi, 2017

Pada Gambar 5 diatas, ditunjukkan lokasi RTH yang berada diantara Lab. Teknik Energi dan Gedung Kuliah I (11); disamping Gedung Kuliah I (12); dan di depan Student Center (13). Berdasarkan hasil survey lapangan, Taman yang berada diantara Lab. Teknik Energi dan Gedung Kuliah I serta Taman yang berada disamping Gedung Kuliah I berpotensi untuk dikembangkan menjadi ruang publik bagi mahasiswa untuk menjalankan berbagai aktivitas, sehingga dapat memenuhi fungsi sosial budaya. Oleh karenanya dibutuhkan penyediaan fasilitas seperti kursi, meja, proteksi cuaca, lampu penerangan, jaringan listrik, dan jaringan internet. Sedangkan untuk Taman yang berada didepan Student Center, saat ini sudah optimal digunakan dan telah memenuhi fungsi estetika.

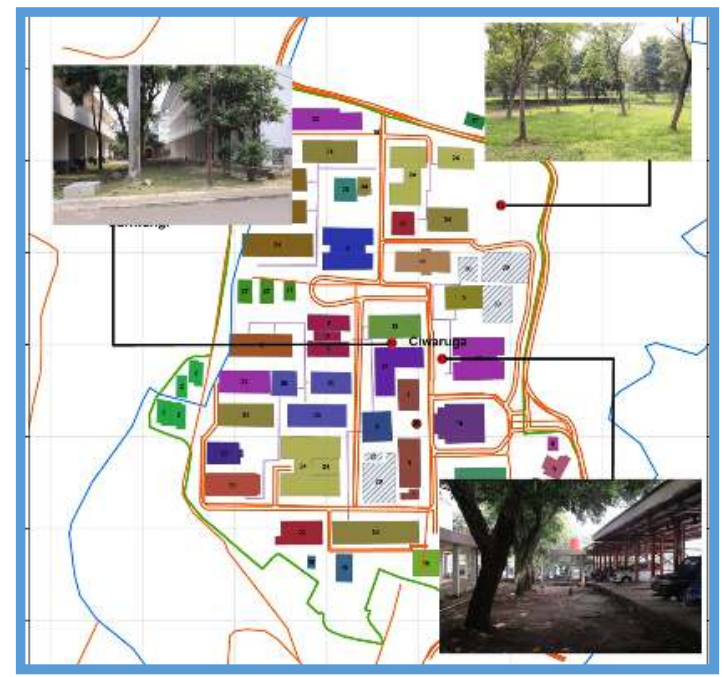

Gambar 6 Peta Potensi Lokasi Strategis ke-6 Pengembangan RTH Kampus POLBAN Sumber: Hasil Dokumentasi, 2017 
Jurnal Planologi Vol. 15, No. 1, April 2018 Available : http://jurnal.unissula.ac.id/index.php/psa

Gambar 6 menunjukkan RTH yang berada diantara Gedung MTRI dan Gedung Kuliah II (14); Taman diantara Kantin Koperasi dan Parkir Dosen (15); dan Taman diarea parkir Mahasiswa (16). Berdasarkan hasil pengamatan, Taman yang berpotensi untuk dikembangkan yakni Taman yang terletak diantara Gedung MTRI dan Gedung Kuliah II serta Taman diarea Parkir Mahasiswa. Kedua Taman tersebut dapat digunakan sebagai ruang publik, terutama untuk Taman yang berada diarea parkir mahasiswa yang dikenal dengan "Taman Wood Ball" berpotensi menjadi pusat ruang publik mengingat lokasinya yang strategis dan luas lahannya yang lebih besar dibanding Taman lainnya, serta dilalui oleh setiap mahasiswa dari berbagai jurusan. Oleh karenanya diharapkan selain dapat memenuhi fungsi sosial budaya, dapat juga dimanfaatkan untuk memenuhi fungsi estetika dengan menambahkan sentuhan arsitektural seperti adanya kolam air mancur, penanaman beragam jenis pepohonan yang dapat digunakan sebagai sarana penelitian dan rekreaasi. Oleh karenanya dibutuhkan beberapa penambahan fasilitas yang menunjang, seperti kursi, meja, lampu taman, jaringan listrik, dan jaringan internet.

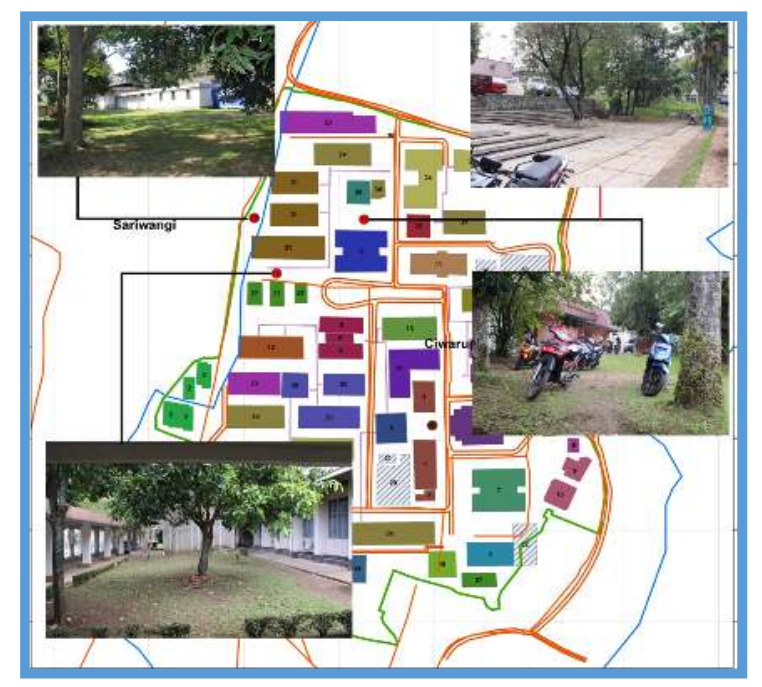

Gambar 7 Peta Potensi Lokasi Strategis ke-7 Pengembangan RTH Kampus POLBAN Sumber: Hasil Dokumentasi, 2017

Lokasi RTH sebagaimana ditunjukkan pada Gambar 7, berada dibelakang Kantin MKU(17); disebelah Barat Gedung Teknik Komputer (18); dan di depan Gedung Teknik Komputer (19). Berdasarkan hasil pengamatan, ketiga lokasi tersebut sangat berpotensi untuk dimanfaatkan sebagai ruang publik bagi mahasiswa, oleh karenanya perlu disediakan berbagai macam fasilitas seperti disediakannya meja, kursi, proteksi cuaca, jaringan listrik, dan jaringan internet. Hal tersebut diharapkan dapat 
menciptakan Taman yang memenuhi fungsi sosial budaya, dimana mahasiswa dapa memanfaatkan Taman tersebut sebagai tempat menjalankan berbagai aktivitas, seperti mengerjakan tugas kuliah, diskusi kelompok, dan kegiatan lainnya yang dapat menstimulus bakat dan kreatifitas mahasiswa Polban.

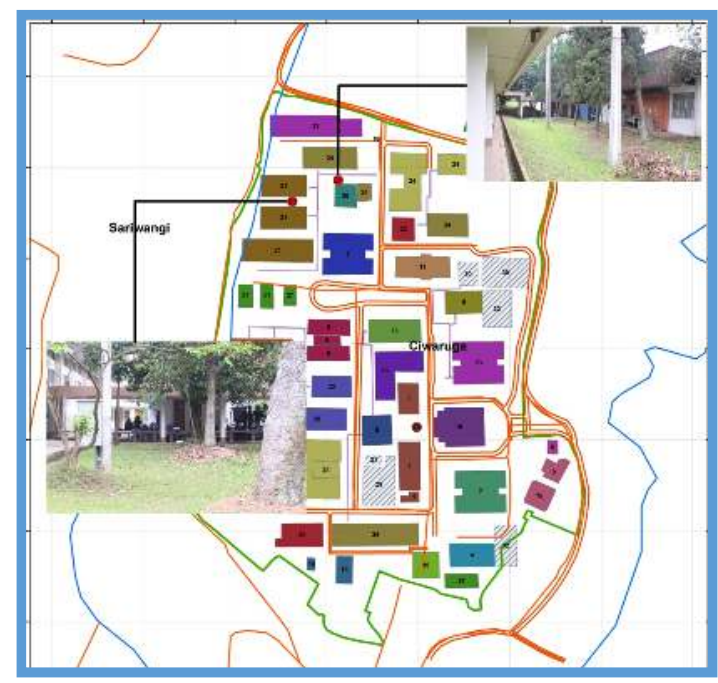

Gambar 8 Peta Potensi Lokasi Strategis ke-8 Pengembangan RTH Kampus POLBAN Sumber: Hasil Dokumentasi, 2017

Gambar 8 diatas, menunjukkan lokasi RTH yang berada diantara Gedung Teknik Komputer dan Gedung Lab. Teknik Telekomunikasi (20) serta diantara Gedung Welding Training Center dan Gedung Lab. Teknik Mesin atas (21). Berdasarkan hasil observasi lapangan, kedua lokasi tersebut berpotensi untuk dapat dikembangkan sebagai ruang publik mahasiswa untuk melaksanakan beragam aktivitas. Oleh karenanya perlu dilengkapi dengan fasilitas seperti meja, kursi, proteksi cuaca, dan jaringan listrik, sehingga diharapkan Taman tersebut memikili fungsi sosial budaya.

Berdasarkan hasil pemetaan RTH yang sudah dilakukan disekitar Polban, dapat diidentifikasi Taman-taman yang berpotensi untuk dilakukan pengembangan. Dari 21 (dua puluh satu) lokasi RTH, terdapat 16 (enam belas) lokasi RTH yang berpotensi untuk pemanfaatan RTH di Kampus Polban, sebagaimana ditunjukkan pada Tabel 1.

Tabel 1 Hasil Identifikasi Lokasi Potensi Penyediaan dan Pemanfaatan RTH di Kampus Polban

\begin{tabular}{|c|l|c|}
\hline NO & \multicolumn{1}{|c|}{ Lokasi } & $\begin{array}{c}\text { Penyediaan dan } \\
\text { Pemanfaatan }\end{array}$ \\
\hline 1 & Taman Menara Air Utara & Potensi \\
\hline 2 & Taman di samping gedung laboratorium Aeronautika & Potensi \\
\hline 3 & Taman di depan gedung administrasi niaga & Potensi \\
\hline 4 & Taman di samping gedung Pujasera & Potensi \\
\hline
\end{tabular}


Jurnal Planologi Vol. 15, No. 1, April 2018

Available : http://jurnal.unissula.ac.id/index.php/psa

\begin{tabular}{|c|l|c|}
\hline NO & \multicolumn{1}{|c|}{ Lokasi } & $\begin{array}{c}\text { Penyediaan dan } \\
\text { Pemanfaatan }\end{array}$ \\
\hline 5 & Taman di depan lab. Tekinik Kimia & Optimal \\
\hline 6 & Taman di samping Asrama Mahasiswa & Optimal \\
\hline 7 & Taman di area Parkir Mahasiswa & Optimal \\
\hline 8 & Taman di antara gedung U dan Gedung Teknik Refrigerasi & Potensi \\
\hline 9 & Taman di antara gedung U dan Gedung Lab Teknik Mesin & Potensi \\
\hline 10 & Taman di depan Gedung Akuntansi & Potensi \\
\hline 11 & Taman di antara gedung lab Teknik Energi dan gedung kuliah I & Potensi \\
\hline 12 & Taman di samping Gedung Kuliah I & Optimal \\
\hline 13 & Taman di depan Student Center & Potensi \\
\hline 14 & Taman diantara gedung MTRI dan gedung kuliah II & Optimal \\
\hline 15 & Taman diantara Kantin Koperasi dan Parkir Dosen & Potensi \\
\hline 16 & Taman di area Parkir Mahasiswa & Potensi \\
\hline 17 & Taman di belakang Kantin MKU & Potensi \\
\hline 18 & Taman di sebelah barat Gedung Teknik Komputer & Potensi \\
\hline 19 & Taman di depan Gedung Teknik Komputer & Potensi \\
\hline 20 & $\begin{array}{l}\text { Taman di antara Gedung teknik komputer dan gedung lab } \\
\text { teknik telekomunikasi }\end{array}$ & Potensi \\
\hline 21 & $\begin{array}{l}\text { Taman di antara Gedung Welding Training Center dan Gedung } \\
\text { Lab. Teknik Mesin atas }\end{array}$ & \\
\hline
\end{tabular}

Sumber: Hasil Survey Lapangan, 2017

Berdasarkan hasil wawancara kepada pihak pengelola aset yakni Kepala Bidang Aset dan Rumah Tangga, pemanfaatan RTH di kawasan Kampus Polban sebagai fungsi sosial budaya yakni untuk mewadahi beragam aktivitas warga kampus sehingga bisa dijadikan sebagai ruang publik dan ruang belajar terbuka (open learning space) untuk melaksanakan kegiatan pembelajaran diluar ruang kelas. Adapun pengaturan waktu pemanfaatan RTH tesebut yakni pada hari kerja di jam operasional Kampus Polban, terkecuali jika ada kegiatan atas persetujuan kampus memanfaatkan RTH diluar jam kerja Kampus Polban. Selain itu, RTH di kawasan Kampus Polban juga berpotensi menunjang fungsi estetika sehingga dapat menjadi icon kampus dan juga berpotensi menunjang fungsi ekonomi dengan menanam tanaman budidaya sehingga dapat menghasilkan tanaman atau buah yang dapat di konsumsi bahkan dijual sebagai produk kampus. Upaya tersebut diharapkan dapat menjadi peluang bagi Polban untuk melakukan penyediaan dan pemanfaatan RTH kampus yang produktif dan berkinerja tinggi, sehingga RTH dapat menunjang berbagai aktivitas seluruh warga kampus. Adapun lokasi, luas, dan jenis potensi yang mungkin dikembangkan pada RTH Kampus Polban, sebagaimana ditunjukkan pada Tabel 2. 
Jurnal Planologi Vol. 15, No. 1, April 2018

Available : http://jurnal.unissula.ac.id/index.php/psa

Tabel 2 Potensi Penyediaan dan Pemanfaatan RTH di Kampus Polban

\begin{tabular}{|c|c|c|c|}
\hline NO & Lokasi & $\begin{array}{l}\text { Luas } \\
\text { Lahan }\end{array}$ & Jenis Potensi (fungsi RTH) \\
\hline 1 & Taman Menara Air Utara & $961,2 \mathrm{~m}^{2}$ & Estetika (Icon Kampus) \\
\hline 2 & $\begin{array}{lcc}\text { Taman di samping } & \text { gedung } \\
\text { laboratorium } & \text { Aeronautika } & \end{array}$ & $620,1 \mathrm{~m}^{2}$ & $\begin{array}{l}\text { Sosial-Budaya (Ruang Publik dan } \\
\text { open learning space) }\end{array}$ \\
\hline 3 & $\begin{array}{l}\text { Taman di depan gedung } \\
\text { administrasi niaga }\end{array}$ & $184,6 \mathrm{~m}^{2}$ & $\begin{array}{l}\text { Sosial-Budaya (Ruang Publik dan } \\
\text { open learning space) } \\
\text { Ekonomi (tanaman berbuah) }\end{array}$ \\
\hline 4 & Taman di samping gedung Pujasera & $765 \mathrm{~m}^{2}$ & $\begin{array}{l}\text { Sosial-Budaya (Ruang Publik) } \\
\text { Ekonomi (budidaya tanaman) }\end{array}$ \\
\hline 5 & Taman di area Parkir Mahasiswa & $945 \mathrm{~m}^{2}$ & Sosial-Budaya (ruang publik) \\
\hline 6 & $\begin{array}{l}\text { Taman di antara gedung } U \text { dan } \\
\text { Gedung Lab Teknik Mesin }\end{array}$ & $\begin{array}{c}511,98 \\
\mathrm{~m}^{2}\end{array}$ & $\begin{array}{l}\text { Sosial-Budaya (Ruang Publik dan } \\
\text { open learning space) }\end{array}$ \\
\hline 7 & Taman di depan Gedung Akuntansi & $242,9 \mathrm{~m}^{2}$ & $\begin{array}{l}\text { Sosial-Budaya (Ruang Publik dan } \\
\text { open learning space) }\end{array}$ \\
\hline 8 & $\begin{array}{l}\text { Taman di di antara gedung lab } \\
\text { Teknik Energi dan gedung kuliah I }\end{array}$ & $\begin{array}{c}513,02 \\
\mathrm{~m}^{2}\end{array}$ & $\begin{array}{l}\text { Sosial-Budaya (Ruang Publik dan } \\
\text { open learning space) }\end{array}$ \\
\hline 9 & Taman disaping Gedung Kuliah I & $212 \mathrm{~m}^{2}$ & $\begin{array}{l}\text { Sosial-Budaya (Ruang Publik dan } \\
\text { open learning space) }\end{array}$ \\
\hline 10 & $\begin{array}{l}\text { Taman diantara gedung MTRI dan } \\
\text { gedung kuliah II }\end{array}$ & $407 \mathrm{~m}^{2}$ & $\begin{array}{l}\text { Sosial-Budaya (Ruang Publik dan } \\
\text { open learning space) }\end{array}$ \\
\hline 11 & Taman di area Parkir Mahasiswa & $\begin{array}{c}6.393,052 \\
\mathrm{~m}^{2}\end{array}$ & $\begin{array}{l}\text { Sosial-Budaya (ruang publik) } \\
\text { Estetika (Center Point RTH) }\end{array}$ \\
\hline 12 & Taman di belakang Kantin MKU & $686,4 \mathrm{~m}^{2}$ & Sosial-Budaya (ruang publik) \\
\hline 13 & $\begin{array}{l}\text { Taman di sebelah barat Gedung } \\
\text { T.Kom }\end{array}$ & $314 \mathrm{~m}^{2}$ & Sosial-Budaya (ruang publik) \\
\hline 14 & $\begin{array}{l}\text { Taman di depan Gedung Teknik } \\
\text { Komputer }\end{array}$ & $138,7 \mathrm{~m}^{2}$ & $\begin{array}{l}\text { Sosial-Budaya (Ruang Publik dan } \\
\text { open learning space) }\end{array}$ \\
\hline 15 & $\begin{array}{lcc}\text { Taman di antara } & \text { Gedung } & \text { teknik } \\
\text { komputer dan } & \text { lab } & \text { teknik } \\
\text { telekomunikasi } & & \end{array}$ & $\begin{array}{l}250,16 \\
\mathrm{~m}^{2}\end{array}$ & $\begin{array}{l}\text { Sosial-Budaya (Ruang Publik dan } \\
\text { open learning space) }\end{array}$ \\
\hline 16 & $\begin{array}{l}\text { Taman di antara Gedung Welding } \\
\text { Training Center dan Lab. Teknik } \\
\text { Mesin }\end{array}$ & $247,6 \mathrm{~m}^{2}$ & $\begin{array}{l}\text { Sosial-Budaya (Ruang Publik dan } \\
\text { open learning space) }\end{array}$ \\
\hline
\end{tabular}

Sumber: Hasil Survey Lapangan, 2017

\section{KESIMPULAN DAN SARAN}

\section{Kesimpulan}

Berdasarkan hasil identifikasi potensi pemanfaatan RTH di Kampus Polban, dari 21 titik lokasi RTH yang ada, hanya 16 lokasi yang berpotensi untuk dioptimalkan pemanfaatannya melalui fungsi tambahan (ekstrintik) RTH. Pemanfaatan RTH di kawasan Kampus Polban dapat digunakan sebagai fungsi sosial budaya yakni untuk mewadahi beragam aktivitas warga kampus sehingga bisa dijadikan sebagai ruang publik dan ruang belajar terbuka (open learning space) untuk melaksanakan kegiatan pembelajaran diluar ruang kelas. Adapun pengaturan waktu pemanfaatan RTH tersebut 
yakni pada hari kerja di jam operasional Kampus Polban, terkecuali jika ada kegiatan atas persetujuan kampus yang dapat memanfaatkan RTH diluar jam kerja Kampus Polban. Selain itu, RTH di kawasan Kampus Polban juga berpotensi menunjang fungsi estetika sehingga dapat menjadi icon kampus dan juga berpotensi menunjang fungsi ekonomi dengan menanam tanaman budidaya sehingga dapat menghasilkan tanaman atau buah yang dapat di konsumsi bahkan dijual sebagai produk kampus.

\section{Saran}

Guna mendukung optimasi pemanfaatan RTH kampus, Polban perlu memenuhi kriteria keidealan pemanfaatan RTH sebagai ruang publik dan ruang belajar luar (open learning space). Oleh karenanya, RTH dapat dilengkapi dengan fasilitas yang menunjang seperti: meja, kursi, jaringan listrik, jaringan internet, proteksi cuaca, dan lampu taman.

\section{DAFTAR PUSTAKA}

Anonim. (2007). UU No.26 Tahun 2007 tentang Penataan Ruang

Anonim. (2007). Peraturan Menteri Pekerjaan Umum Nomor 1 Tahun 2007 tentang Penataan Ruang Terbuka Hijau Kawasan Perkotaan.

Anonim. (2008). Peraturan Menteri Pekerjaan Umum Nomor 5 Tahun 2008 tentang Pedoman Penyedian dan Pemanfaatan Ruang Terbuka Hijau di Kawasan Perkotaan.

Anonim. (2009). Peraturan Gubernur Jawa Barat Nomor 21 Tahun 2009 tentang Petunjuk Pelaksanaan Peraturan Daerah Provinsi Jawa Barat Nomor 1 Tahun 2008 Tentang Pengendalian Pemanfaatan Ruang Kawasan Bandung Utara.

Anonim. (2016). Keputusan Bupati Bandung Barat Nomor 530/Kep.166-KLH/ 2016 tentang Izin Lingkungan Kegiatan Kampus POLBAN.

Arifin, H. S. A dan Nurhayati. (2000). Pemeliharaan Taman. Penebar Swadaya. Jakarta. Arikunto, Suharsimi. (2006). Prosedur Penelitian. Jakarta: PT. Rineka Cipta.

Brown, B Malcolm \& Joan K Lippicott. (2003). Learning Spaces : More than Meets the Eye. Diakses dari http://net.educause.edu/ir/library/pdf/EQM0312.pdf, tanggal 1111-2017.

Carmona dkk. (2003). Public Space Urban Space: The Dimension of Urban Design. Architectural Press: London.

Creswell, John W. (2009). Research Desain: Qualitative, Quantitative, and Mix Methods Approaches. London: Sage Publications, Inc. 
Jurnal Planologi Vol. 15, No. 1, April 2018

Available : http://jurnal.unissula.ac.id/index.php/psa

Educause. (2011). 7 Things You Should Know about The Modern Learning Commons.

Diakses dari https://net.educause.edu/ir/library/pdf/ELI7071.pdf, tanggal 11-112017.

Hakim, Rustam. (2004). Arsitektur Lansekap, Manusia, Alam dan Lingkungan. Jakarta: FALTLUniversitas Trisakti.

Mudjiman, Haris. (2007). Belajar Mandiri. Surakarta : UPT Penerbitan dan Percetakan UNS (UNS Press).

Irfan, Edwin at. al. (2009). Penataan Ruang Sebuah Cermin Peradaban. Jakarta: Direktorat Jenderal Penataan Ruang Departemen Pekerjaan Umum.

McDaniel, Stephanie. (2014). Every Space is a Learning Space. Saint Paul : BWBR Architects.

Nasution, (2003). Metode Penelitian Naturalistik Kualitatif. Bandung: PT Tarsito.

Riswandi. (2004). Ruang Terbuka Hijau. Diakses dari http://www.damandiri.or.id, tanggal 12-04-2017

Siahaan, James. (2010). Ruang Publik : Antara Harapan dan Kenyataan. Buletin Tata Ruang, Edisi Juli-Agustus 2010.

Sugiama, A.G. (2008). Metode Riset Bisnis dan Manajemen (Edisi pertama). Bandung: Guardaya Intimarta.

Sugiyono. (2010). Metode Penelitian Pendidikan Pendekatan Kuantitaf, Kualitatif, dan $R \& D$. Bandung: Alfabeta.

Sunaryo, R.G.; Soewarno, N; Ikaputra; Setiawan, B. (2010). Posisi Ruang Publik Dalam Transformasi Konsepsi Urbanitas Kota Indonesia. Paper Kumpulan Makalah pada Seminar Nasional Riset Arsitektur \& Perencanaan 1, IAP DIY APRF - JUTAP UGM, Yogyakarta.

Tarigan, Robinson. (2010).Perencanaan Pembangunan Wilayah Edisi Revisi. Jakarta: Bumi Aksara.

The International Alliance of Research Universities. (2007). Green Guide For Universities. 